\title{
Evaluation of Microorganisms with Sulfidogenic Metabolic Potential under Anaerobic Conditions
}

\author{
Isabel Kimiko Sakamoto*, Sandra Imaculada Maintinguer, Julia Sumiko Hirasawa, Maria \\ Angela Tallarico Adorno and Maria Bernadete Amâncio Varesche \\ Departamento de Hidráulica e Saneamento; Escola de Engenharia de São Carlos; Universidade de São Paulo; \\ Av. João Dagnone, 1100; 13563-120; São Carlos - SP - Brasil
}

\begin{abstract}
The aim of this work was to identify groups of microorganisms that are capable of degrading organic matter utilizing sulfate as an electron acceptor. The assay applied for this purpose consisted of running batch reactors and monitoring lactate consumption, sulfate reduction and sulfide production. A portion of the lactate added to the batch reactors was consumed, and the remainder was converted into acetic, propionic and butyric acid after 111 hours of operation These results indicate the presence of sulfate-reducing bacteria (SRB) catalyzing both complete and incomplete oxidation of organic substrates. The sulfate removal efficiency was $49.5 \%$ after 1335 hours of operation under an initial sulfate concentration of $1123 \mathrm{mg} / \mathrm{L}$. The SRB concentrations determined by the most probable number (MPN) method were $9.0 \times 10^{7}$ cells $/ \mathrm{mL}$ at the beginning of the assay and $8.0 \times 10^{5}$ cells $/ \mathrm{mL}$ after 738 hours of operation.
\end{abstract}

Key words: sulfate-reducing bacteria, lactate, Most Probable Number, organic acids

\section{INTRODUCTION}

The sulfate ion is the most stable form of sulfur compound that exists in nature and is present in sanitary sludge and various types of industrial wastewater at varying concentrations. Under anaerobic conditions, sulfate-reducing bacteria (SRB) convert sulfate ions $\left(\mathrm{SO}_{4}^{-2}\right)$ into sulfide $\left(\mathrm{S}^{-2}\right)$. These SRB are capable of utilizing different substrates, including some hydrocarbons, such as phenols, which makes it possible to use SRB for wastewater treatment and bioremediation of areas contaminated by chemicals such as petroleum.

In the absence of an electron acceptor, SRB are capable of growing via acetogenesis or fermentation using pyruvate, lactate or ethanol as an organic substrate. In mixed cultures containing sulfate, such as those found in bioreactors, SRB compete with acidogenic bacteria, hydrogenotrophic methanogenic archaea and acetoclastics for the available substrates. This competition determines the amount of methane and sulfide produced and what type of end product is obtained from the anaerobic conversion of organic matter (Lens et al. 1998).

According to Colleran (1994), there are theoretically four different metabolic processes that involve SRB: a) complete oxidation of the products of acidogenesis to form carbon dioxide and reduce sulfate to sulfide; b) incomplete oxidation of acidogenesis products to form acetate; c) syntrophic degradation of intermediate compounds, such as organic acids and alcohols, by acetogenic bacteria that are associated with SRB and utilize hydrogen; and d) fermentative growth of SRB in the presence of propionate and ethanol.

*Author for correspondence: sakamoto@sc.usp.br 
In the absence of sulfate, a syntrophic association occurs with acetoclastic and hydrogenotrophic bacteria.

O'Reilly and Colleran (2006) studied the effect of the different COD/sulfate ratios $(16,8,4$ and 2) on the syntrophic and competitive interactions between various microbial groups. SRB species were unable to out-compete methane-producing archaea species for acetate at influent $\mathrm{COD} / \mathrm{SO}_{4}{ }^{(-2)}$ ratios as low as 2. The SRB were observed to play a more significant role in the conversion of hydrogen but did not become completely dominant. Hydrogenotrophic methanogenic archaea were responsible for hydrogen utilization at an influent $\mathrm{COD} /$ sulfate ratio of 16 and were still dominant when the ratio was reduced to 4 . Hydrogenotrophic SRB assumed a more influential role only when the $\mathrm{COD} /$ sulfate ratio was reduced to 2. SRB species were the dominant population responsible for the degradation of propionate at all of the $\mathrm{COD} /$ sulfate ratios examined.

Lactate is currently employed as an excellent organic substrate enabling the enrichment, isolation and enumeration of and identification of proper culture conditions for bacteria similar to Desulfovibrio sp. and Desulfotomaculum sp. This substrate can be completely oxidized by several types of sulfate-reducing bacteria.

The study of these bacteria is of great interest to various industries, especially the navigation and petroleum industries, given that they are the most affected by the corrosion caused by SRB (IlhanSungur et al. 2007). These microorganisms may also be used in the bioremediation of areas contaminated by petroleum and hydrocarbons due to their nutritional versatility.

The aim of this work was to identify groups of microorganisms involved in the degradation of organic matter using sulfate as an electron acceptor. Sodium lactate was used as a carbon source in an assay to determine the sulfidogenic metabolic potential. The experiments measured lactic acid consumption, sulfate reduction and sulfide production. We conducted microscopic examinations and quantified SRB using the most probable number (MPN) at the beginning and the end of the experiment.

\section{MATERIALS AND METHODS}

The experiments were carried out using anaerobic granular sludge from an Upflow Anaerobic Sludge Blanket (UASB) that treats poultry slaughterhouse wastewater (Dakar Poultry S/A, SP-Brazil).

Batch reactors were prepared in triplicate in $2 \mathrm{~L}$ Duran ${ }^{\circledR}$ flasks filled with $1 \mathrm{~L}$ of reaction medium and $10 \%(\mathrm{v} / \mathrm{v})$ inoculum, then sealed under an $\mathrm{N}_{2} / \mathrm{CO}_{2}(70: 30 \%)$ atmosphere. The reactors were incubated at $30^{\circ} \mathrm{C} \pm 1{ }^{\circ} \mathrm{C}$, with agitation at 120 rpm. The mineral medium (Zinder et al. 1984) consisted of the following chemicals dissolved in distilled water: $\mathrm{NH}_{4} \mathrm{Cl}, 0.5 \mathrm{~g} / \mathrm{L} ; \mathrm{K}_{2} \mathrm{HPO}_{4}, 0.4 \mathrm{~g} / \mathrm{L}$; $\mathrm{MgCl}_{2} \cdot 6 \mathrm{H}_{2} \mathrm{O}, 0.1 \mathrm{~g} / \mathrm{L} ; \mathrm{CaCl}_{2} \cdot 2 \mathrm{H}_{2} \mathrm{O}, 0.05 \mathrm{~g} / \mathrm{L}$; rezasurin, $0.001 \mathrm{~g} / \mathrm{L}$; a trace-metal solution, 10 $\mathrm{mL} / \mathrm{L}$ (Zinder and Koch 1984); and sodium bicarbonate $(1 \mathrm{~g} / \mathrm{L})$, a vitamin solution $(1 \mathrm{~mL} / \mathrm{L})$ (Touzel and Albagnac 1983), sodium lactate (2.24 $\mathrm{g} / \mathrm{L})$ and sodium sulfate $(1.12 \mathrm{~g} / \mathrm{L})$. Sodium sulfide $(0.5 \mathrm{~g} / \mathrm{L})$ was used as a reducing agent. The $\mathrm{COD} /$ sulfate ratio was 1.3 .

The organic acids present in the reactors (lactic, acetic, propionic and butyric acids) were analyzed via HPLC in a Shimadzu system, as described by Lazaro et al. (2008).

Analyses of sulfate, sulfide, COD and total volatile solids (TVS) were performed according to APHAAWWA-WEF (2005).

SRB were quantified using the multiple tubes technique (Most Probable Number, MPN) at the beginning of the experiment and after $738 \mathrm{hr}$. The same media and lactate concentration described above were used for the MPN assay. The concentration of sodium sulfide was $0.04 \mathrm{~g} / \mathrm{L}$.

SRB were detected by collecting a $0.5 \mathrm{~mL}$ sample, diluting it serially and adding it to a tube with 1.0 $\mathrm{mL}$ of ferrous sulfate $(1 \mathrm{~g} / \mathrm{L})$. The presumed SRB population was positive in tests that measure ferrous sulfide (black precipitate). The SRB population was identified using a combination of positive (black precipitate) and negative (no black precipitate) tests, according to APHA-AWWAWEF (2005).

The morphologies of various bacteria observed in the sulfidogenic assay and MPN samples were examined via phase contrast microscopy (Olympus BX60-FLA microscope), and images were captured with a digital camera (Evolution QE, Media Cybernetics Inc., USA). Image Pro-Plus 4.5 software was used for image analysis.

\section{RESULTS AND DISCUSSION}

A portion of the lactic acid added to the batch 
reactors was consumed and converted into organic acids, such as acetic, propionic and butyric acid, which indicated the presence of SRB catalyzing the complete and incomplete oxidation of the organic substrate. The temporal variation of the production of organic acids (over 111 hours of operation) is presented in Figure 1. The data indicated that as lactic acid decreased, the amounts of other acids (mainly acetic acid) increased. Propionic and butyric acid were detected after 40 hours. After 72 hours of operation, propionic acid was not detected, whereas the percentages of acetic and butyric acid increased from $62 \%$ and $2.1 \%$ to $92 \%$ and $8.4 \%$, respectively.

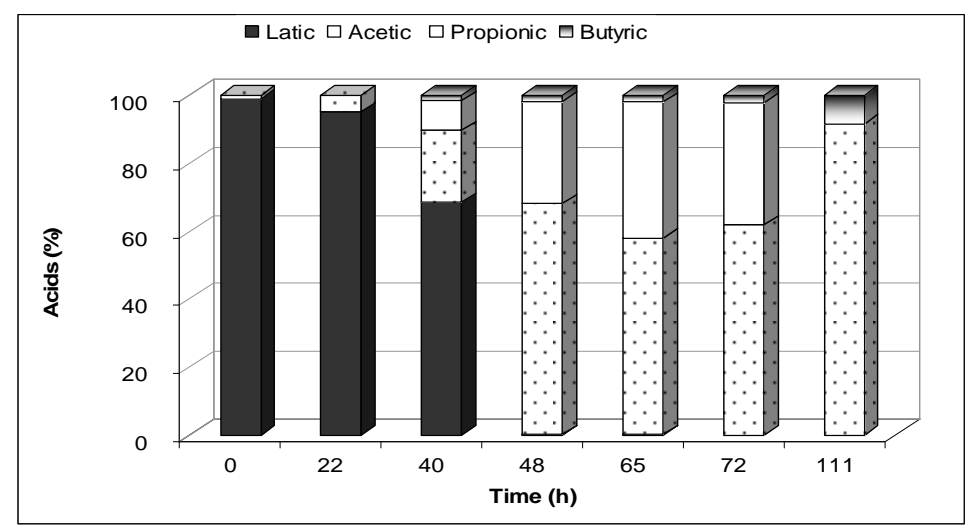

Figure 1 - Proportions (percentages) of the organic acids present in samples from the reactors.

According to Lens et al. (1998), for each $96 \mathrm{~g}$ of sulfate present in wastewater, $64 \mathrm{~g}$ of COD are consumed (COD/sulfate ratio of 0.67$)$. Therefore, there is theoretically sufficient sulfate to completely remove the organic matter present via sulfidogenesis. At COD/sulfate ratios of less than 0.67 , the amount of organic matter is insufficient for complete reduction of sulfate to be achieved, and an external source of carbon must therefore be added if the goal of the treatment is sulfate removal. For wastewater with a $\mathrm{COD} /$ sulfate ratio higher than 0.67 , the complete removal of organic matter will be achieved only if methanogenesis occurs along with the reduction of sulfate (Lens et al. 1998).

The COD/sulfate ratio used in this work was 1.3. The reactors were operated for 1335 hours, with initial and final CODs of $1515 \mathrm{mg} / \mathrm{L}$ and 634 $\mathrm{mg} / \mathrm{L}$, respectively, with $58 \%$ of efficiency. The initial and final sulfate concentrations were 1123 $\mathrm{mg} / \mathrm{L}$ and $567 \mathrm{mg} / \mathrm{L}$, respectively. Therefore, $49.5 \%$ sulfate removal efficiency was achieved. The initial and final values of total volatile solids (TVS) were $16 \mathrm{~g} / \mathrm{L}$ and $21 \mathrm{~g} / \mathrm{L}$, respectively, which indicated biomass growth over the 1335 hours of operation. However, at 738 hours of operation, the TVS value was $16.2 \mathrm{~g} / \mathrm{L}$, which represented almost no change since the beginning of the assay. This result may be related to the storage time of the sludge granules ( \pm 10 months) under refrigeration at $4^{\circ} \mathrm{C}$. These findings indicated that the biomass required a long period of adaptation to the new feeding conditions.

Sarti (2007) used batch reactors fed with mineral medium, as described by Zinder and Koch (1984), with added sodium lactate, sodium acetate, ethanol and sodium sulfate to obtain initial COD/sulfate ratios of 1.1 to 1.5 . This author achieved a COD removal efficiency of 87 to $89 \%$ and a sulfate consumption of 57 to $77 \%$. Under these conditions, the preferential substrate of the SRB was lactate, instead of ethanol or acetate.

The sulfate consumption was greater in the early hours of the assay (Fig. 2). This finding is attributed to the presence of organic substrates such as lactate, acetate, propionate and butyrate. After consumption of these compounds, the remaining sulfate may have been reduced via hydrogenotrophic SRB metabolism, which can utilize carbon dioxide and or other organic acids produced during cell death. However, sulfate reduction under these conditions occurs more slowly.

Figure 2 shows that the sulfide concentration increased as the sulfate concentration was reduced. However, this result may be due to the difficulty involved in measuring sulfide gas and to the loss that may occur during sample collection. The sulfide analysis performed in this study employed liquid samples. 
According to O'Flaherty et al. (1998), SRB use sulfate as a terminal electron acceptor when it is available during the oxidation of organic matter, resulting in the production of hydrogen sulfite
$\left(\mathrm{H}_{2} \mathrm{~S}\right)$. The SRB can be divided into two main groups: those that can completely oxidize organic matter to $\mathrm{H}_{2} \mathrm{~S}$ and $\mathrm{CO}_{2}$ and those that carry out incomplete oxidation, usually forming acetate.

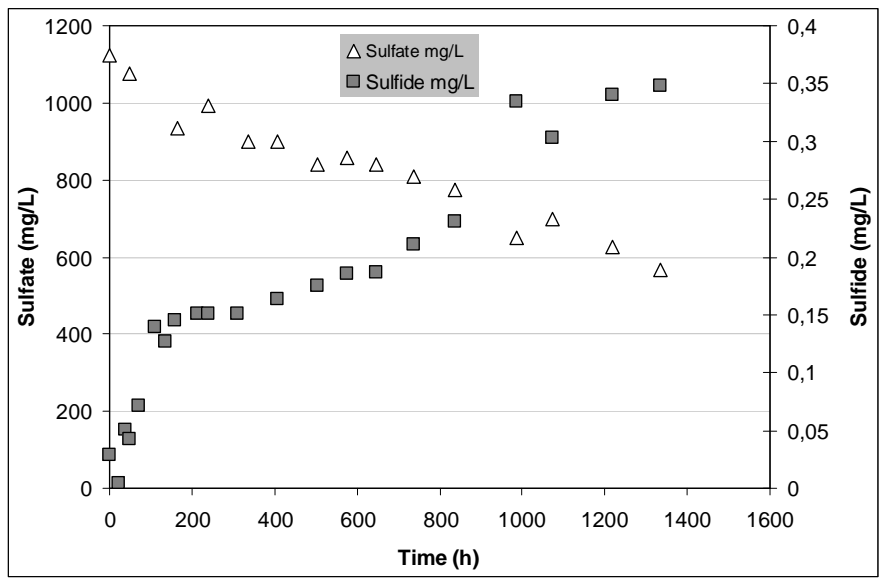

Figure 2 - Average values of the sulfate consumption and sulfide production in the reactors during the assay time.

The reactors fed with lactate plus sulfate contained $9.0 \times 10^{7}$ cells $/ \mathrm{mL}$ and $8.0 \times 10^{5}$ cells $/ \mathrm{mL}$ at the beginning of the experiment and after 738 hours of operation, respectively (Fig.3), indicating that these bacteria were reduced over time in the reactors. Although the values of TVS remained essentially the same over this period of time, the MPN quantification indicated that other microorganisms (anaerobic bacteria) were maintained along with the reduction of SRB. This SRB reduction was most likely due to the absence of an external source of carbon, given that was nearly entirely consumed by 111 hours.

Sarti (2007) also found that the SRB population decreased over time, from $27.9 \%$ to $19.5 \%$, despite an observed sulfate consumption of $77.5 \%$. The author observed that methanogenic archaea were predominant (52.6\%) at the end of the assay.

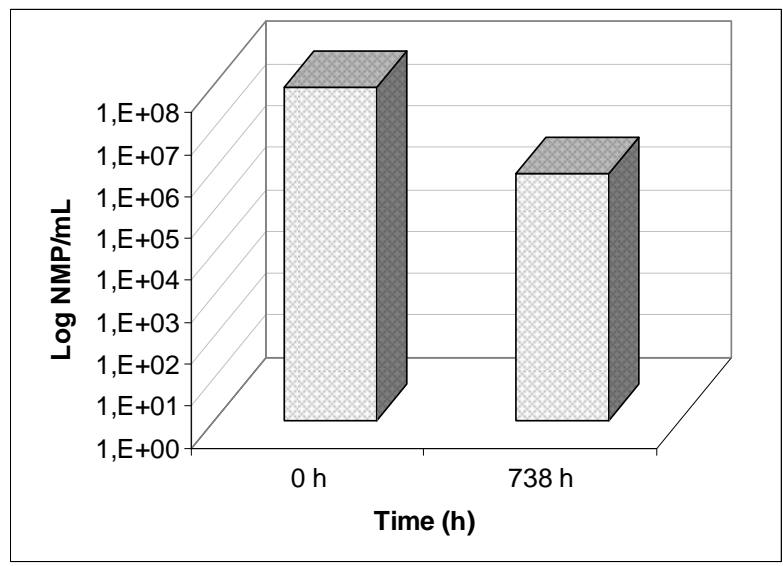

Figure 3 - Quantification of SRB at the beginning of the experiment and after 738 hours of operation.

According to Widdel (1988), SRB compete with methanogenic archaea for hydrogen $\left(\mathrm{H}_{2}\right)$, carbon dioxide $\left(\mathrm{CO}_{2}\right)$ and acetate and with syntrophic bacteria for substrates such as propionate, butyrate and ethanol, which are key intermediates in the overall process of anaerobic digestion.

Domingues et al. (2004) used 2 L Duran ${ }^{\circledR}$ flasks containing media with lactate $(1.8 \mathrm{~g} / \mathrm{L})$ plus sulfate 
$(1.1 \mathrm{~g} / \mathrm{L})$ incubated at $55 \pm 1{ }^{\circ} \mathrm{C}$ and observed SRB concentrations of $3.0 \times 10^{11}$ cells $/ \mathrm{mL}$ initially and $9.0 \times 10^{12}$ cells $/ \mathrm{mL}$ after 55 days of operation.

Sakamoto (1996) utilized 100-mL serum flasks filled with mineral medium, as described by Zinder and Koch (1984), with added sodium acetate and increasing amounts of sodium sulfate, which resulted in carbon/sulfate ratios from 0.36 to 1.35 . They obtained $2.29 \times 10^{4}$ cells $/ \mathrm{mL}$ and $1.51 \times 10^{12}$ cells $/ \mathrm{mL}$ for carbon/sulfate ratios of 0.45 and 0.67 , respectively.

In this work, we used mineral medium as described by Zinder and Koch (1984) with added sodium lactate and sodium sulfate. The quantities of SRB found by Sakamoto (1996) were higher than were found in the present study, most likely because of the addition of external carbon sources and the decreasing sulfate concentrations during the assay, which may have promoted selection for SRB.

The bacteria observed in the granular sludge sample (inoculum) displayed various morphologies, including filaments similar to Methanosaeta sp., coccobacilli, diplococci, curved rods, rods and segmented filaments (Fig. 4a). Ribas et al. (2005) observed similar morphologies in granular sludge collected from an UASB. Additionally, a horizontal-flow anaerobic

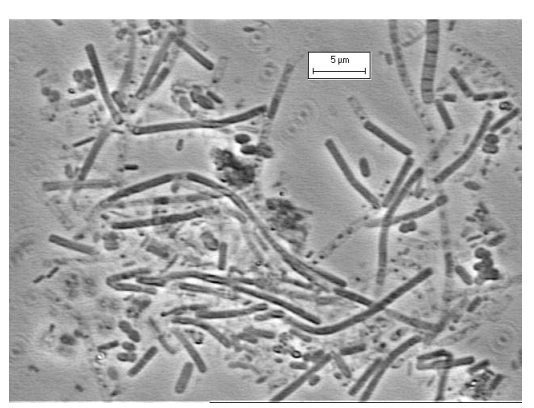

(a)

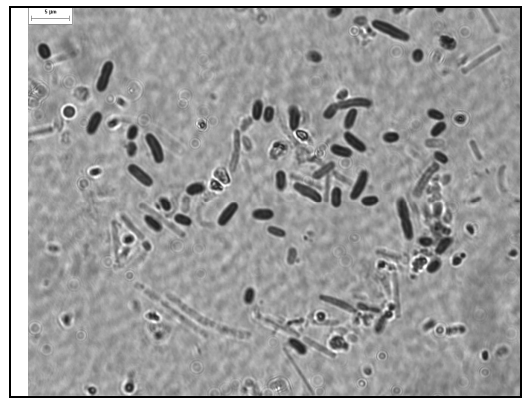

(b) immobilized biomass (HAIB) reactor treating domestic sewage was found to contain rods, cocci, spirochetes, filaments, fluorescent rods and cocci as well as Methanosaeta sp.-like archaeal cells (Lima et al. 2005).

Hirasawa (2003) analyzed the granular sludge used in this work via FISH using the EUB338 and ARC915 probes and found that they detected $44.8 \%$ and $59.5 \%$ of the sample, respectively. These results were similar to the quantification performed by Sarti (2007) using the EUB338, ARC915 and BRS385 probes, which corresponded to $49.8 \%, 56.7 \%$ and $27.9 \%$ of the sample, respectively. Therefore, based on these studies, the inoculum contained a greater proportion of methanogenic archaea than SRB.

Although the granular sludge (inoculum) was predominately methanogenic, several other works have used this sludge to obtain a cellular population capable of removing sulfate (Damianovic et al. 2006; Hirasawa 2007; Sarti 2007). The morphologies observed in the sample obtained at the end of the sulfidogenic assay included rods, curved rods and coccobacilli (Fig. $4 \mathrm{~b})$. The morphologies observed in the final MPN sample $\left(10^{-4}\right.$ dilution $)$ corresponded to coccobacilli, curved rods and rods (Fig. 4c).

Figure 4 - Morphology observed using phase contrast microscopy. (a) In the granular sludge (inoculum), filaments similar to Methanosaeta sp., coccobacilli, diplococci, rods, curved rods and segmented filaments were observed. (b) At the end of the sulfidogenic assay, rods, curved rods and coccobacilli were observed. (c) In the MPN test (dilution $10^{-4}$ ), coccobacilli, rods and curved rods were observed.

\section{CONCLUSIONS}

The organic substrate added in the assay described herein was entirely consumed in 111 hours and was partially converted to other types of acids, such as acetic, propionic and butyric acid. This conversion indicated the existence of the activity of SRB performing both complete and incomplete oxidation of organic substrates.

The batch reactors fed with lactate plus sulfate contained $9.0 \times 10^{7}$ cells $/ \mathrm{mL}$ at the beginning of the experiment and $8.0 \times 10^{5}$ cells $/ \mathrm{mL}$ after 738 hours of operation, which indicated a decrease in the number of these bacteria in the reactors, 
possibly due to the lack of an external carbon source, as it was essentially consumed in 111 hours.

\section{ACKNOWLEDGMENTS}

This research was financially supported by the Conselho Nacional de Desenvolvimento Científico e Tecnológico (CNPq) and the Financiadora de Estudos e Projetos (FINEP).

\section{REFERENCES}

APHA-AWWA-WPCF. Standard Methods for the Examination of Water and Wastewater, $21^{\text {th }}$ ed., Washington, DC, EUA; 2005.

Colleran E. Anaerobic treatment of suphate-containing waste streams. Department of Microbiology University College, Galway, Republic of Ireland; 1994.

Damianovic MHRZ, Sakamoto IK, Foresti E. Biofilm adaptation to sulfate reduction in anaerobic immobilized biomass reactors subjected to different COD/sulfate ratios. Wat Sci Tech. 2006; 54(2): 119126.

Domingues MR, Moraes EM, Vazoller RF, Varesche MBA. Analysis of Microbial Community in Biofilms and Planktonic Cells of Anaerobic Thermophilic Reactors. Braz Arch Biol Technol. 2004; 47(5): 122132.

Hirasawa JS. Evaluation of the microbial community in anaerobic reactor sulfetogênico using fluorescence insitu hybridization (FISH) [Msc. Dissertation]. São Carlos, SP, Brasil: São Carlos School of Engineering, University of São Paulo; 2003.

Hirasawa JS. Evaluation of methanogenesis and sulfidogenesis in presence of oxygen under different ethanol/sulfate ratios using Molecular Biology techniques [PhD Thesis]. São Carlos, SP, Brasil: São Carlos School of Engineering, University SãoPaulo; 2007.

Ilhan-Sungur E, Cansever N, Cotuk A. Microbial corrosion of galvanized steel by a freshwater strain of sulphate reducing bacteria (Desulfovibrio sp.). Corrosion Science. 2007; 49: 1097-1109.

Lazaro CZ, Hirasawa JS, Varesche MBA, Adorno MAT. Development of an HPLC method for the analysis of eleven short chain organic acids in bioproduction of hydrogen. In: XII COLACRO (Congresso Latino-Americano de Cromatografia e Técnicas Relacionadas), Florianópolis, SC, Brasil. 2008.
Lens PNL, Visser A, Janssen AJH, Hulshoff pol LW, Lettinga G. Biotechnological treatment of sulfate-rich wastewaters. Critical Rev. Environ Sci Technol. 1998; 28:41-88.

Lima CAA, Ribeiro R, Foresti E, Zaiat $M$. Morphological Study of Biomass During the Start-Up Period of a Fixed-Bed Anaerobic Reactor Treating Domestic Sewage. Braz Arch Biol Technol. 2005; 48(5): 841-849.

O`Flaherty V, Lens P, Leahy B, Colleran E. Long-Term competition between sulphate-reducing and methaneproducing bacterial during full-scale anaerobic treatment of citric acid production wastewater. Wat. Res. 1998; 32(3): 815-825.

O'Reilly C, Colleran E. Effect of influent COD/SO ${ }_{4}^{-2}$ ratios on mesophilic anaerobic reactor biomass populations: physico-chemical and microbiological properties. FEMS Microbiol Ecol. 2006; 56: 141-153.

Ribas MMF, Chinalia FA, Pozzi E, Foresti E. Microbial Succession Within an Anaerobic Sequencing Batch Biofilm Reactor (ASBBR) Treating Cane Vinasse at 55 C. Braz Arch Biol Technol. 2009; 52(4): 10271036.

Sakamoto IK. Behavior of existing microbial consortium in a methanogenic anaerobic sludge granules, subjected to increasing additions of sulfate. [Msc. Dissertation]. São Carlos, SP, Brasil: São Carlos School of Engineering, University of São Paulo; 1996.

Sarti EL. Oxygen influence on methanogenic archaea and sulfate reducing bacteria's growth in anaerobic batch reactors. [Msc. Dissertation]. São Carlos, SP, Brasil: São Carlos School of Engineering, University of São Paulo; 2007.

Touzel JP, Albagnac G. Isolation and characterization of Methanococcus mazei strain $\mathrm{MC}_{3}$ FEMS Microbiol Lett. 1983; 16: 241-245.

Widdel F. Microbiology and ecology of sulphate and sulfur-reducing bacteria. In: Biology of anaerobic microorganismos: Edited by Zehnder A. J. B. Wiley, New York; 1988. p. 469-586.

Zinder SH, Cardwell SC, Anguish T, Lee M, Koch M. Methanogenesis in a thermofilic $\left(58^{\circ} \mathrm{C}\right)$ anaerobic digestor. Methanothrix sp. as an important acetoclastic methanogen. Appl Environ Microbiol. 1984; 47: 796-807.

Zinder SH, Koch M. Non-aceticlastic methanogenesis from acetate oxidation by a thermophilic syntrophic coculture. Arch Microbiol. 1984; 138: 263-272.

Received: September 16, 2011; Revised: March 9, 2012; Accepted: July 19, 2012. 